\title{
Sintesis dan Aplikasi Nanopartikel Kitosan Sebagai Adsorben Cd dan Antibakteri Koliform
}

\author{
SWARA YUDHASASMITA ${ }^{1}$ DAN ANDHIKA PUSPITO NUGROHO ${ }^{1}$ \\ ${ }^{1}$ Fakultas Biologi, Universitas Gadjah Mada Yogyakarta \\ J1. Teknika Selatan, Sekip Utara, Yogyakarta 55281 \\ email: swarayudha@mail.ugm.ac.id; andhika_pn@ugm.ac.id
}

\begin{abstract}
Chitosan is a derivative compound of chitin which has a linear polysaccharide composed of $\beta$ (1-4)-linked d-glucosamine and N-acetyl-d-glucosamine. This compound is found in shrimp shell. In nanoparticle form, chitosan has a great antibacterial activity and adsorption ability rather than normal form. The aims of this study are to study the effect of concentration chitosan nanoparticle to adsorpt cadmium and its antibacterial effect on coliform. This research was started with synthesis of chitosan nanoparticles using acetic acid $2 \%$ and TPP $0,1 \%$, then the sampel was dried by spray dryer. For cadmium adsorption test was conducted by giving chitosan nanoparticle of $0.1,0.2,0.3$, 0.4 , and $0.5 \mathrm{~g}$, respectively, into Cd solution with the concentration of $7 \mathrm{ppm}$ and was filtered with theWhatman paper number $42(\mathrm{n}=3)$. Cadmium contents in the filtrates and pellets were analyzed by using AAS. For antibacterial test with Salmonella typhimurium andEscherichia coliwere conducted by disc diffusion method, contained of $0.1,0.2,0.3,0.4$, and $0.5 \mathrm{~g}$, respectively, were dissolved in $50 \mathrm{ml}$ of $1 \%$ acetic acid. Data were analyzed by using oneway ANOVA followed by LSD. Based on the results, the optimum adsorption of cadmium present in addition of $0.4 \mathrm{~g} / 50 \mathrm{~mL}$, can reduce Cd concentration by $98,7 \%$. For the antibacterial test, the addition of $0.4 \mathrm{~g} / 50 \mathrm{~mL}$ is the largest zone of inhibition Salmonella thypimuriumand Escherichia coli.
\end{abstract}

Keywords: antibacterial coliform, cadmium adsorbent, chitosan nanoparticle

\section{INTISARI}

Kitosan merupakan senyawa derivat dari kitin yang memiliki linear polisakarida yang tersusun dari $\beta$-(1-4)-linked d-glucosamine dan $N$-acetyl-d-glucosamine. Senyawa ini banyak terkandung dalam kulit udang. Dalam bentuk nanopartikel, kitosan memiliki aktivitas antibakteri dan adsorpsi yang lebih baik jika dibandingkan dalam bentuk biasa. Tujuan penelitian ini adalah untuk mempelajari pengaruh konsentrasi kitosan nanopartikel terhadap pengikatan cadmium $(\mathrm{Cd})$ dan efeknya pada aktivitas antibakteri koliform. Penelitian ini dimulai dengan sintesis senyawa nanopartikel kitosan dengan larutan asam cuka $2 \%$ dan TPP 0,1 , kemudian larutan dikeringkan dengan spray drier. Uji adsorpsi logam cadmium dilakukan dengan menambahkan 0,$1 ; 0,2 ; 0,3 ; 0,4$ dan 0,5 gram nanopartikel kitosan ke dalam larutan cadmium dengan konsentrasi 7 ppm,dan disaring dengan kertas Whatman no $42(\mathrm{n}=3)$. Kandungan $\mathrm{Cd}$ dalam filtrat dan residu ditentukan dengan AAS. Uji antibakteri terhadap Salmonella typhimurium dan Escherichia coli dilakukan dengan metode cakram, yang mengandung 0,$1 ; 0,2 ; 0,3 ; 0,4$ dan 0,5 gram nanopartikel kitosan dalam $50 \mathrm{ml}$ asam cuka $1 \%$. Data kemudian dianalisis dengan oneway ANOVA dilanjutkan dengan LSD, apabila ditemukan beda nyata. Hasil yang diperoleh menunjukkan bahwa pengikatan optimum Cd terjadi pada penambahan kitosan sebanyak $0,4 \mathrm{~g} / 50 \mathrm{~mL}$ asam cuka, dengan penurunan sebesar 98,7\%. Pada uji antibakteri, penambahan kitosan $0,4 \mathrm{~g} / 50 \mathrm{~mL}$ asam cuka menunjukkan penghambatan tertinggi terhadap pertumbuhan S. typhimurium dan E. coli.

Kata kunci: adsorben cadmium, antibakteri koliform, nanopartikel kitosan 


\section{PENDAHULUAN}

Pertumbuhan industri di Indonesia telah menimbulkan dampak merugikan bagi lingkungan. Konsentrasi pencemar dalam ekosistem akuatik, seperti pencemar organik, mikrobia patogen, dan logam berat, menunjukkan peningkatan dari tahun ke tahun, mengarah pada penurunan kualitas lingkungan. $\operatorname{Kadmium}(\mathrm{Cd})$ merupakan salah satu logam yang telah diketahui menjadi pencemar ekosistem akuatik. Menurut Bradl (2005) sumber kadmium terbesar berasal dari penambangan yang mencapai $65 \%$. Dibandingkan dengan logam timbal dan nikel, kadmium memiliki emisi terbesar di atmosfer hingga mencapai 6 juta ton per tahunnya. Selain digunakan dalam pembuatan baterai, kadmium digunakan dalam pembuatan stabilisator plastik, pembakaran batu bara, dan pelapis logam antikorosif. Di alam, kadmium tersedia dalam bentuk $\mathrm{Cd}^{2+}$ dan bersifat toksik pada konsentrasi rendah (USGS, 2008).

Kehadiran senyawa kadmium di alam menyebabkan berbagai permasalahan yang serius terhadap organisme yang hidup di sekitarnya. Kehadiran senyawa kadmium menyebabkan berbagai penyakit seperti kanker paru-paru, kanker prostat, dan kanker pankreas. Pada tumbuhan, kehadiran kadmium menyebabkan efek toksik seperti mempengaruhi aktivitas enzim pada fotosintesis, mengurangi kadar klorofil, mempengaruhi pembukaan serta penutupan stomata pada daun. Sedangkan pada manusia, kadmium menyebabkan gangguan metabolisme kalsium, vitamin $\mathrm{D}$, kolagen, dan menyebabkan degenerasi tulang seperti osteomalachia (Bradl, 2005).

Bakteri koliform merupakan kelompok bakteri yang dijadikan sebagai indikator pencemaran lingkungan perairan. Menurut surat keputusan Dirjen POM Nomor: 037267/B/SK/VII/89, batas maksimum pencemaran koliform di lingkungan perairan dengan menggunakan metode MPN, yaitu $<3$ individu per gram atau per $\mathrm{ml}$, sedangkan batas untuk mikrobia E. coli dan Salmonella thypi sebesar 0 . Kehadiran pencemar mikrobia dan logam di lingkungan perairan menyebabkan penurunan kualitas lingkungan.
Berbagai metode untuk mengatasi pencemaran air telah dilakukan, seperti elektro dialisis, membran pemisah, dan adsorpsi. Di antara metode tersebut, biosorpsi merupakan metode yang diakui dapat mengatasi pencemaran logam berat. Nanopartikel kitosan merupakan kitosan dalam bentuk nanopartikel yang dapat mencapai ukuran hingga $1000 \mathrm{~nm}$ dan memiliki zeta potensial positif berkisar antara $+20 \mathrm{mV}$ hingga $+60 \mathrm{mV}$ (Calvo et al., 1997). Dalam bentuk nanopartikel, kitosan memiliki kemampuan adsorpsi yang lebih baik, karena memiliki permukaan yang spesifik, ukuran kecil, dan efek ukuran kuantum, sehingga efisiensi dalam menyerap ion logam menjadi lebih tinggi (Sivakami et al., 2013). Di samping itu, kemampuan kitosan dalam bentuk nanopartikel juga memiliki aktivitas yang besar dalam menghambat pertumbuhan bakteri karena dapat langsung teruptake ke dalam sel bakteri (Cauerhff et al., 2013). Penelitian ini dilakukan untuk mengetahui efektivitas nanopartikel kitosan dalam menangani pencemaran air seperti bakteri koliform dan kadmium.

\section{METODE}

\section{Preparasi Nanopartikel Kitosan.}

Preparasi nanopartikel kitosan mengacu pada metode (Calvo et al., 1997). Nanopartikel kitosan disintesis dengan metode ionic gelation. Konsentrasi kitosan kitosan dilarutkan dalam larutan asam asetat dengan variasi konsentrasi kitosan: $0,05 \%$; $0,1 \%$; $0,5 \%$; dan $1 \%(\mathrm{w} / \mathrm{v})$. Konsentrasi asam asetat 1,75 kali lebih tinggi dari konsentrasi kitosan. Kemudian TPP dilarutkan dalam akuades dengan konsentrasi yang sama yaitu $0,05 \%$; $0,1 \% ; 0,5 \%$ dan $1 \%(\mathrm{w} / \mathrm{v})$. Variabel volume larutan TPP $(0,25 ; 1,0 ; 2,0 ; 2,5$; dan $3 \mathrm{~mL})$ di tambahkan ke dalam $5 \mathrm{~mL}$ larutan kitosan dan diaduk dengan magnetic stirrer. Sedangkan untuk optimasi dalam penelitian ini konsentrasi kitosan dalam asam asetat yaitu 3 gram dalam $1 \mathrm{~L}(0,3 \%)$ dan konsentrasi asam asetat yang digunakan yaitu 2\%. Sebanyak $200 \mathrm{ml}$ Tripolifosfat $(1 \mathrm{mg} / \mathrm{mL})$ ditambahkan secara perlahan ke dalam larutan kitosan dan diaduk dengan magnetic stirrer dengan kecepatan $1200 \mathrm{rpm}$. Kemudian nanopartikel dikeringkan 
dengan menggunakan Spray Dryer pada suhu $180^{\circ} \mathrm{C}$

Karakterisasi Nanopartikel Kitosan. Sampel nano kitosan dalam bentuk cair dianalisis ukurannya dengan menggunakan alat PSA (Particle Size Analyzer) di Laboratorium MIPA Institut Pertanian Bogor. Pembentukan nanopartikel terjadi pada range 10-1000 nanometer.

Uji Adsorpsi Nanopartikel Kitosan. Uji adsorpsi dilakukan dengan menambahkan sebanyak 0,$1 ; 0,2 ; 0,3 ; 0,4$ dan 0,5 gram nanopartikel kitosan ke dalam Erlenmeyer 100 $\mathrm{mL}$. Selanjutnya $50 \mathrm{~mL}$ larutan kadmium 7 ppm dimasukkan ke dalam Erlenmeyer, pengadukan dilakukan dengan menggunakan magnetic stirrer selama 15 menit. Larutan tersebut disaring dengan kertas whatman no. 42, selanjutnya dilakukan analisis kandungan $\mathrm{Cd}$ dalam filtrat (supernatan) dan pelet yang diperoleh.

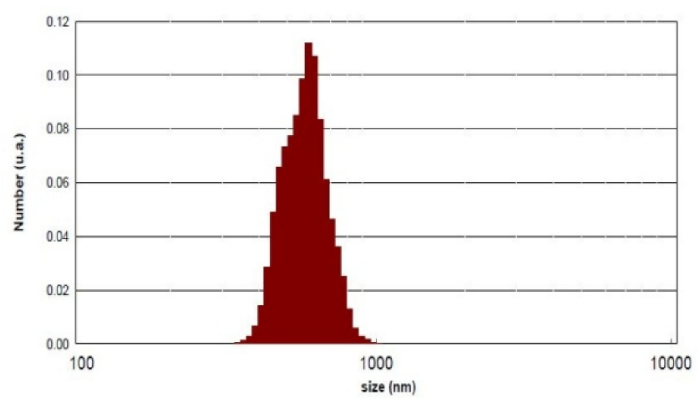

Uji Antibakteri Dengan Metode Cakram. Uji antibakteri dilakukan dengan menggunakan bakteri koliform $E$. coli dan $S$. typhimurium. Sebanyak 0,$1 ; 0 ; 2 ; 0,3 ; 0,4$; dan 0.5 gram nanopartikel kitosan dilarutkan kedalam asam asetat $1 \%$ volume $50 \mathrm{~mL}$. Kemudian kertas cakram whatman 42 dimasukkan kedalam berbagai konsentrasi kitosan tersebut dan diletakkan kedalam medium NA yang telah mengandung bakteri koliform. Petridisk kemudian diinkubasi selama 1 hari dengan suhu ruangan.

Analisis Data. Data kandungan Cd dalam filtrat dan pellet, dan zona jernih, dianalisis dengan one way ANOVA $(\alpha=5 \%)$, dengan besarnya penambahan nanopartikel kitosan sebagai variabel independen. Apabila hasil ANOVA menunjukkanbeda nyata maka dilanjutkan dengan pengujian LSD.

\section{HASIL}

Gambar 1. Analisis Particle Size Analyzer berdasarkan jumlah partikel dan volume

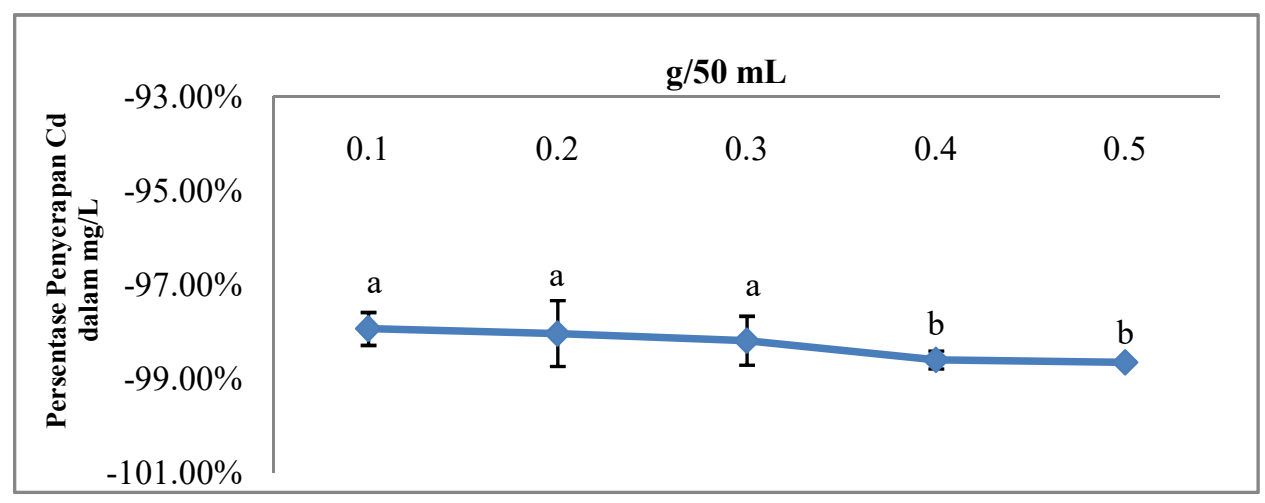

Gambar 2. Penurunan kandungan Cd dalam medium cair 


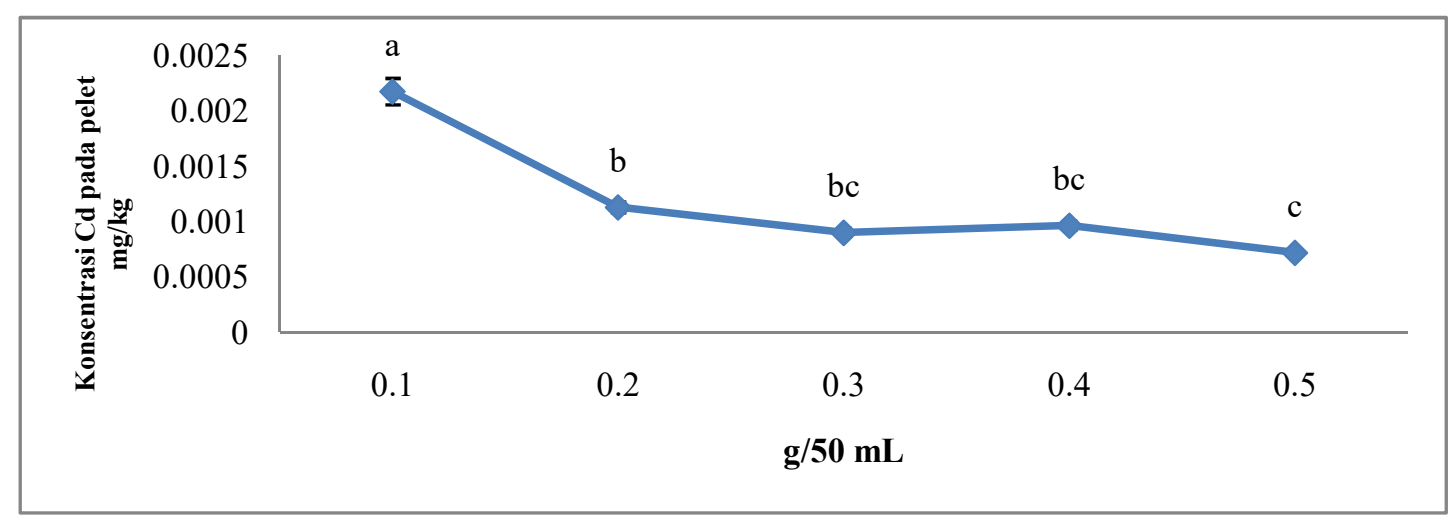

Gambar 3. Analisis Cadmium pada Filtrat dan Residue
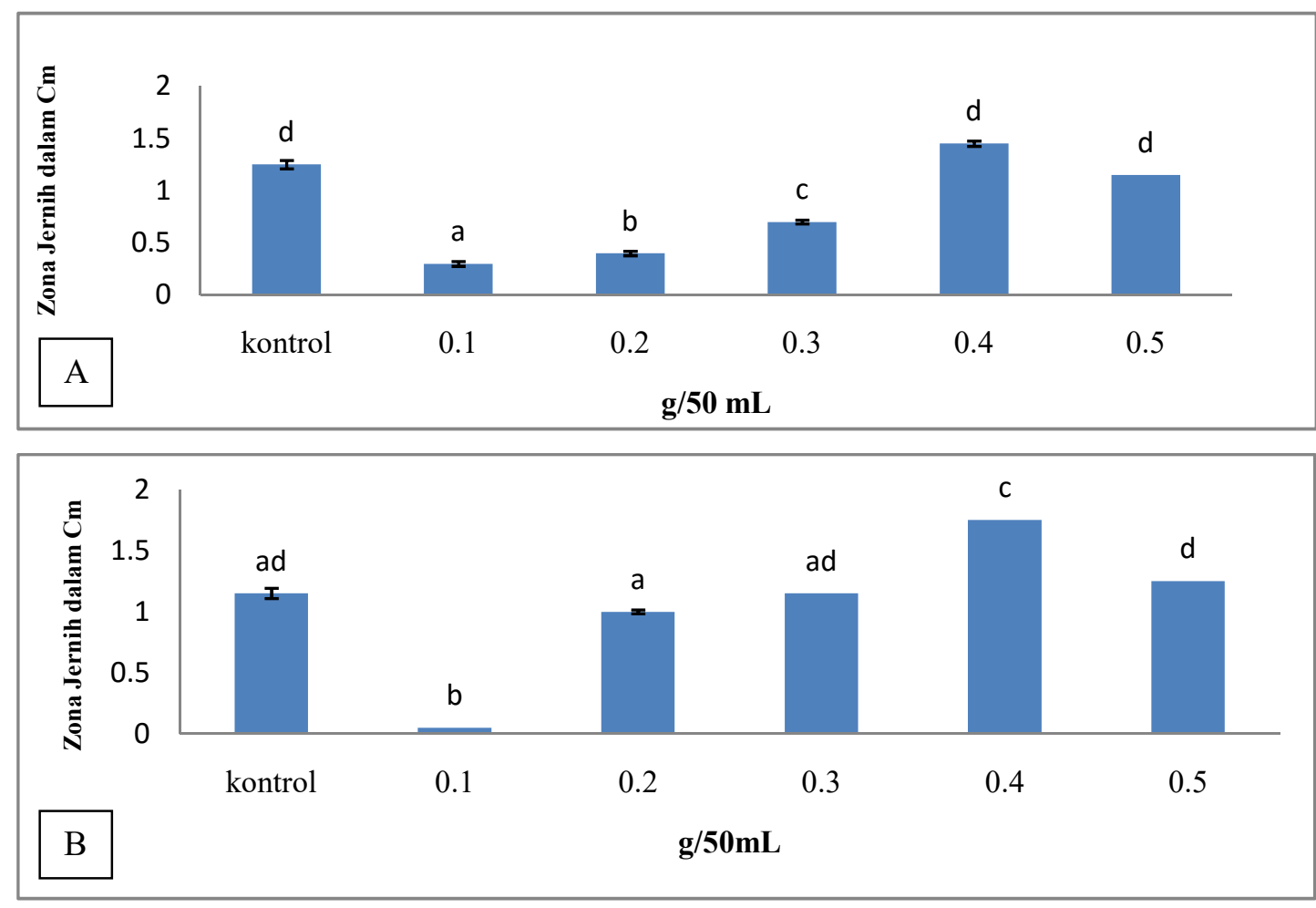

Gambar 4. Diameter zona jernih (A) Escherichia coli dan (B) Salmonella typhimurium

\section{PEMBAHASAN}

Sintesis Nanopartikel Kitosan Dengan Optimasi. Pada penelitian ini, pembuatan nanopartikel mengacu pada metode Calvo et al. (1997) dengan optimasi. Metode ini dimulai dengan melarutkan kitosan sebanyak $0,3 \% \mathrm{ke}$ dalam asam asetat $2 \%$ dengan kondisi $\mathrm{pH} 3.92$. Hal ini dikarenakan pada konsentrasi $0,3 \%$ kitosan dapat membentuk nanopartikel serta menghasilkan serbuk yang lebih banyak dibandingkan konsentrasi yang rendah. Penggunaan asam asetat $2 \%$ sebagai pelarut kitosan, karena sifat kitosan yang tidak dapat larut dalam air. Konsentrasi asam asetat 2\% merupakan konsentrasi yang tepat agar kitosan dapat dilarutkan dengan sempurna. Kitosan hanya dapat larut dalam pelarut dan $\mathrm{pH}$ yang asam (Aranaz et al., 2009). Kemudian ditambahkan larutan TPP $0,1 \%$ dengan menggunakan pipet tetes dengan perbandingan larutan kitosan dan TPP, yaitu 1:5. Fungsi penambahan TPP ini yaitu sebagai reagen crosslinker. Penambahan reagen TPP dengan konsentrasi $0,1 \%$ merupakan konsentrasi yang optimum untuk membentuk partikel berukuran nano. 
Dari hasil analisis PSA, volume partikel terkecil dalam penelitian ini yaitu $426,69 \mathrm{~nm}$. Sedangkan partikel yang memiliki volume terbesar, yaitu terdapat dalam partikel yang berukuran 616,76 nm. Pada analisis jumlah partikel, jumlah paling sedikit berukuran $389,15 \mathrm{~nm}$, sedangkan jumlah partikel terbanyak berukuran 589,00-616,76 nm. Menurut Mohanraj and Chen (2006), nanopartikel merupakan butiran atau partikel padat yang memiliki ukuran $10-1000 \mathrm{~nm}$. Berdasarkan ukuran tersebut, sampel larutan pada penelitian ini telah berbentuk nanopartikel. Bentuk ukuran partikel banyak dipengaruhi oleh beberapa faktor diantaranya konsentrasi TPP, konsentrasi larutan kitosan, rasio volume larutan kitosan dan TPP, lama pengadukan, kecepatan pengadukan, dan lamanya waktu penyimpanan (Calvo et al.,1997; Mardliyati dkk., 2012; Fabregas et al., 2013; Supitjah et al., 2011).

Uji Adsorpsi Nanopartikel Kitosan. Pada penelitian ini sampel yang dianalisis kandungan logam yaitu pada filtrat dan pelet nanopartikel kitosan. Penambahan nanopartikel kitosan ke dalam medium cair yang mengandung $\mathrm{Cd} \quad(7 \mathrm{ppm})$ menyebabkan penurunan kandungan $\mathrm{Cd}$ dalam medium tersebut (Gambar 2). Penurunan tertinggi terjadi pada medium cair dengan penambahan $0,5 \mathrm{~g} / 50 \mathrm{~mL}$ nanopartikel kitosan, yaitu sebesar 98,7\%. Berdasarkan gambar tersebut, semakin besar penambahan nanopartikel kitosan, maka penurunan kandungan $\mathrm{Cd}$ dalam medium cair (filtrat) semakin besar. Namun, peningkatan jumlah nanopartikel kitosan yang ditambahkan pada medium cair menyebabkan penurunan kandungan $\mathrm{Cd}$ dalam medium secara signifikan $(\mathrm{P}<0,05)$. Berdasarkan uji LSD, penambahan nanopartikel kitosan optimum terjadi pada penambahan $0,4 \mathrm{~g} / 50 \mathrm{~mL}$.

Penurunan kandungan $\mathrm{Cd}$ dalam medium cair (filtrat) (Gambar 2) disebabkan pengikatan $\mathrm{Cd}$ oleh nanopartikel kitosan. Hal ini ditunjukkan dengan peningkatan kandungan Cd dalam nanopartikel tersebut (Gambar 3). Analisis pelet kandungan nanopartikel kitosan menunjukkan bahwa pada setiap perlakuan memiliki perbedaan nyata. Pada proses adsorpsi, pH larutan kadmium yaitu 7,66 sedangkan untuk kecepatan putaran yaitu 1200 rpm. Pengikatan tertinggi terjadi pada penambahan $0,1 \mathrm{~g} / 50 \mathrm{~mL}$ nanopartikel, dengan kandungan kadmium mencapai $0.002 \mathrm{mg} / \mathrm{kg}$.

Sedangkan pada perlakuan terendah, yaitu pada pemberian $0,5 \mathrm{~g} / 50 \mathrm{~mL}$, pengikatan hanya sebesar $0,00072 \mathrm{mg} / \mathrm{kg}$. Hasil tersebut tidak sesuai dengan penelitian sebelumnya mengenai uji adsorpsi logam berat dengan menggunakan nanopartikel kitosan. Hal ini dapat dikarenakan pada saat proses penyaringan dengan menggunakan kertas saring, nanopartikel yang tersaring masih banyak menempel pada bagian permukaan kertas. Hal ini dapat dilihat dengan semakin sedikitnya berat nanopartikel kitosan yang dikeringkan dibandingkan pada saat perlakuan. Selain itu, penurunan ini dapat optimum pada $0,1 \mathrm{~g} / 50 \mathrm{~mL}$ dikarenakan konsentrasi larutan $\mathrm{Cd}$ awal yang relatif rendah. Hal ini disertai dengan volume larutan $\mathrm{Cd}$ yang relatif sedikit yaitu $50 \mathrm{~mL}$ sehingga membuat proses pengadukan tidak berjalan dengan baik. Berdasarkan pada penelitian Sivakami et al. (2013), menyatakan bahwa dengan perlakuan konsentrasi awal yang berbeda, dan dosis adsorben yang sama, akan berpengaruh dalam proses penyerapan yang terjadi. Semakin besar konsentrasi awal larutan logam, maka semakin besar penyerapan yang terjadi. Selain itu, besarnya adsorben yang ditambahkan merupakan faktor yang mempengaruhi penurunan logam. Hal ini dikarenakan kehadiran gugus amina pada nanopartikel kitosan.

Pengikatan logam oleh nanopartikel kitosan dipengaruhi oleh beberapa faktor, antara lain kecepatan pengadukan, $\mathrm{pH}$, waktu pengadukan, dan konsentrasi awal larutan mengandung logam.

Uji Antibakteri Nanopartikel Kitosan. Dalam penelitian ini, penggunaan bakteri $E$. coli dan $S$. typhimurium merupakan representasi bakteri yang mencemari perairan. Uji antibakteri dilakukan dengan melarutkan nanopartikel kitosan ke dalam asam asetat $1 \%$. Asam asetat digunakan sebagai pelarut karena sifat kitosan yang tidak dapat larut dalam air, hanya dapat larut dalam kondisi $\mathrm{pH}$ yang asam.

Gambar 4 menunjukkan diameter zona jernih pada $E$. coli setelah pemberian 
nanopartikel kitosan pada medium NA. Hasil tersebut menunjukkan bahwa semakin tinggi pemberian nano partikel kitosan, maka zona jernihnya semakin besar. Kemampuan antibakteri nanopartikel pada $S$. typhimurium menunjukkan hasil yang berbeda pada $E$. coli.

Berdasarkan analisis LSD dapat diketahui bahwa perlakuan optimum terjadi pada perlakuan $0,4 \mathrm{~g} / 50 \mathrm{~mL}$. Hal ini sama seperti uji antibakteri pada E. coli. Pada perlakuan 0,4 $\mathrm{g} / 50 \mathrm{~mL}$, nanopartikel kitosan tidak mengalami agregasi partikel. Sedangkan pada perlakuan $0,5 \mathrm{~g} / 50 \mathrm{~mL}$ nanopartikel mengalami agregasi partikel sehingga memiliki aktivitas antibakteri yang lebih rendah.

Menurut Coma et al. (2002) dalam Goy et al. (2009), aktivitas antimikrobia pada kitosan memiliki 3 mekanisme yang berbeda. Pada mekanisme pertama disebabkan adanya interaksi antara muatan positif pada molekul kitosan dengan muatan negatif pada membran sel mikrobia. Interaksi tersebut bertindak sebagai gaya elektrostatis antara gugus $\mathrm{NH}_{3}{ }^{+}$ yang terprotonasi dan residu negatif yang bersaing dengan $\mathrm{Ca}^{2+}$ pada sisi elektronegatif permukaan membran sel. Interaksi elektrostatis menyebabkan perubahan sifat permeabilitas membrane, sehingga memicu ketidakseimbangan tekanan osmotik internal yang akibatnya dapat menghambat pertumbuhan mikroorganisme tersebut. Selain itu, dengan adanya interaksi elektrostatis terjadi hidrolisis peptidoglikan pada dinding mikroorganisme, menyebabkan keluarnya elektrolit intraselular seperti ion potassium dan molekul seperti protein dan asam nukleat.

Pada mekanisme kedua, kemampuan kitosan dalam bentuk nanopartikel dapat menetrasi ke dalam sel dinding bakteri, bergabung dengan DNA, dan menghambat sintesis mRNA, dan transkripsi DNA (Sudarshan et al., 1992 dalam Goy et al., 2009).

Pada mekanisme ketiga, pembentukan khelasi dari logam, yang dapat menekan elemen spora dan mengikat nutrien esensial pertumbuhan mikrobia. Kemampuan kitosan dalam mengikat logam disebabkan adanya gugus amina dalam kitosan, sehingga dapat menguptake kation logam dengan khelasi. Hal ini menyebabkan molekul kitosan pada bakteri mengelilingi logam kompleks dan terjadi blok beberapa aliran nutrisi, sehingga menyebabkan kematian sel mikrobia (Papineau et al., 1991 dalam Goy et al., 2009).

\section{KESIMPULAN}

Pada penelitian ini dapat disimpulkan sebagai berikut:

1. Sintesis nanopartikel kitosan dipengaruhi oleh konsentrasi TPP dan konsentrasi kitosan dalam asam asetat.

2. Nanopartikel kitosan dapat menurunkan kandungan $\mathrm{Cd}$ dalam medium cair dengan penambahan yang optimum sebesar 0,4 gr/50mL.Partikel tersebut juga menunjukkan penghambatan optimum pada pertumbuhan Salmonella typhimurium dan Escherichia coli.

\section{UCAPAN TERIMAKASIH}

Terima kasih yang sedalam-dalamnya penulis sampaikan kepada Dr. Ario Setiadi yang telah memberikan bantuan dana selama proses penelitian.

\section{DAFTAR PUSTAKA}

Aranaz I, Marian M, Ruth H, Ines P, Beatriz M, Niuris A, Gemma G, and Angeles H. 2009. Functional Characterization of Chitin and Chitosan. J.Current Chemical Biology. vol 3: 203-230.

Bradl HB. 2005. Heavy Metals in the Environmet. Holland: Elsevier. pp 98-103. Calvo P, Remũnan-Lopez C, Vila-Jato JL, Alonso MJ. 1997. Novel Hydrophilic Chitosan-Polyethylene Oxide Nanoparticles As Protein Carriers. J. Applied Polymer Science. vol 63: 125-132.

Cauerhff A, Yanina NM, German AI, Guillermo RC. 2013. Nanotoxicology and Nanomedicine. Chapter 2. Newyork: Springer. pp 63-69.

Fabregas A, Mi narroa F, Garcia-Montoyaa E, Perez-Lozanoa P, Carrillo C, Sarratea R, Sancheza N, Ticoa BJR, Sũne-Negrea JM. 2013. Impact of Physical Parameters on Particle Size and Reaction Yield When using the Ionic Gelation Method to Obtain Cationic Polymeric Chitosan- 
Tripolyphosphate Nanoparticles. Int $J$ Pharm. vol 446(1-2): 199-204.

Goy RC, Duglas B, Odilio BGA. 2009. A Review of the Antimicrobial Activity of Chitosan. Polimeros: Clencia e Technologia. vol 19(3): 241-247.

Mardliyati E, Sjaikhurrizal E, Damai RS. 2012. Sintesis Nanopartikel KitosanTrypolphosphate dengan Metode Gelasi Ionik : Pengaruh Konsentrasi dan Rasio Volume Terhadap Karakteristik Partikel. Prosiding Seminar Ilmu Pengetahuan dan Teknologi Bahan. hal 90-93.
Mohanraj VJ and Chen Y. 2006. Nanoparticles-A Review. Tropical Journal of Pharmaceutical Research. vol 5(1): 561-573.

Sivakami MS, Thandapani G, Jayachandran V, Hee SJ, Se KK, Sudha PN. 2013. Preparation and Characterization of Nano Chitosan for Treatment Wastewaters. Int J Biol Macromol. vol 57: 204-211. doi: 10.1016/j.ijbiomac.2013.03.005.

USGS. 2008. Mineral Commodity Summaries, Kadmium. Washington: United States Government Printing Office. pp 42-43. 